Øivin Andersen

\title{
Fagspråk som forskningsdisiplin (2. del)
}

\begin{abstract}
This article deals with the object of study for LSP. After stressing the general importance of studying LSP (Language for Specific Purposes) (section 2), attention is focused on basic methods, models and definition types used in attempts at drawing a line of demarcation between LSP and LGP (Language for General Purposes) (section 3). Four alternative approaches to the relationship between LSP and terminology are discussed in section 4 . In section 5 the object of study is discussed in more detail. The concept subject field is seen as being related to the concepts tacit knowledge and communicative competence. The article concludes that the most fruitful study of LSP is the themes or subect matter of texts.
\end{abstract}

The first part of this article has been printed in HERMES 3 (1989), pp. 73-98.

\section{Hva er FS's studieobjekt?}

Kan vi identifisere et veldefinert studieobjekt for FS? En achillæshel i definisjonene av FS er, som vi påpekte i 2 ovenfor, at ingen prøver å presisere hva fag eller fagområde er. Vi får inntrykk av at et fagområde betraktes som en slags lukket, statisk enhet.

Som Kuhn påpeker, er intet fagområde statisk. Alle fag endrer seg over tid, og disse endringene nedfeller seg i et fags begrepsapparat. Som eksempel nevner Kuhn oppdagelsen av oksygenet på slutten av 1700-tallet. Oksygenteorien om forbrenning førte til store omveltninger i kjemien (Kuhn op.cit., 56). Dette førte til behov for nye begreper og nye termer.

Hvis et velordnet og logisk stringent begrepssystem representerer et fagområde, tvinges man til å konkludere med at kjemien før og etter oppdagelsen av oksygenet er to forskjellige fag, eller rettere: at den nye kjemien erstatter den gamle, som ikke lenger er gyldig. Vi får så et nytt begrepssystem og en ny harmoni.

Men overgangen fra ett paradigme til et annet er ikke gjort over natten. Gamle og nye paradigmer kan leve i konflikt med hverandre innenfor ett og samme vitenskapelige domene i lang tid, og konkurrere med hverandre (Kuhn op.cit., 77ff).

Et fag og et fagområde er altså dynamisk, ikke statisk. Det fører til at fagets begrepsapparat, dets terminologi, er dynamisk. Dette er et stort dilemma for klassifikasjonslæren: Fagområder fremstilles i statiske takso- 
nomier som ofte gir et misvisende bilde av, og tilslører, virkeligheten (jf Dahlberg 1974, 118ff). Dette er samme type problem man støter på i statisk synkron lingvistisk beskrivelse av språk, særlig hvis man ser på systemet som en lukket enhet (som Saussure gjorde).

Hvis vi skal komme noen vei med dette dilemmaet, er det kanskje bedre å ta utgangspunkt i emneområder. En viktig del av arbeidet med å kartlegge fagområder (som forskningsmessige aktivitetsområder) vil da bestå i å se nærmere på hvilke temaer de ledende forskerne er opptatt av. En naturlig måte å gjøre det på, er å analysere tematisk de dokumentene eller tekstene hvor forskningsaktiviteten beskrives og diskuteres.

Det aktivitetsområdet som primært beskjeftiger seg med dette er informasjons- og dokumentasjonslæren (iod) (jf Laisiepen et al 1980). Generelt kan man si at iod er opptatt av å lage indekseringssystemer og tematiske hierarkier for effektiv gjenfinning av dokumenter i store dokumentmasser. Som TL er iod sterkt normativ, og ønsker å holde gjenfinningssystemenes antall elementer på et lavest mulig nivå. Som Hoffmann påpeker, er tekstlingvistisk innsikt et viktig grunnlag for aktiviteter innen iod (Hoffmann 1983, 59).

De tematiske hierarkiene i iod fremstilles som forskjellige fra TL's begrepssystemer, som oppfattes som de eneste som kan klassifisere "vitenskapelige forestillinger" (Wüster 1971, 98).

Vi kan i vår sammenheng stille spørsmålet om denne forskjellen er reell. Skyldes den at TL ikke har klargjort sitt forhold til fagområde (det som Wüster kaller Sachgebiet)? Vil, i et større perspektiv, et fagområde falle sammen med tematikken i summen av de dokumentene som kan sies å utgjøre en naturlig helhet? Snarere er det vel slik at ikke bare tematikk, men også tradisjoner er medvirkende faktorer når man skal avgjøre hva som faller inn under et fagområde. Derfor vil nok en tematisk klassifikasjon kunne bryte med en fagtaksonomi. På den annen side vil en tematisk klassifikasjon gi et mer reelt bilde av den faglige verden. Dessuten er det lettere å forestille seg at en tematikk som er enhetlig og koherent i større grad lar seg analysere i et velordnet begrepssystem.

Det primære i FS er overføring av data og kunnskap. Det denotative aspektet blir derfor overordnet. Våre temaområder blir dermed samtidig også kunnskapsområder i vitenskapelige fagspråk. Man prøver altså å identifisere kunnskapsområder ved å studere de forskningsmessige aktivitetsområdene, idet man antar at det er en vekselvirkning mellom praksis og kunnskap. 
Den kunnskapen det her er snakk om er kunnskap både om språket og om verden rundt oss: Den kunnskap som fagmannen har akkumulert på sitt fagområde inkluderer også kunnskap om fagområdets begreper.

Et sentralt spørsmål er om denne kunnskapen også omfatter den type intuitiv, taus kunnskap som Chomsky kaller tacit knowledge. Kan i så fall denne kunnskapen defineres som en fagspråksfølelse som kan brukes som akseptabilitetskriterium for FS?

Roald svarer ja på første spørsmål og nei på det andre:

"M.a.o. bedømmes bruken av et uttrykksmiddel som akseptabelt/ikke akseptabelt på grunnlag av en fagspråksfølelse, altså en intuitiv evne? Svaret må selvsagt bli nei. Vi vet empirisk at FS bare beherskes etter en innlæringsprosess som går parallelt med innlæring av fagets viten. Fagspråklig akseptabilitet er ikke av noen annen natur enn i AS, men reflekterer et mer presist og finmasket forhold til , og kunnskap om, virkeligheten" (Roald 1986a, 179).

Som sagt kan ordformer i tekster ha samme uttrykk i AS som i FS. Likevel vil en lekmann som leser en slik tekst kunne avgjøre om kraft og energi $\mathrm{i}$ en tekst brukes fagspråklig eller allmennspråklig. Det synes klart at også lekmannen har en intuisjon om hva som er vitenskapelig terminologi og hva som ikke er det. Wierzbicka har gjennom flere unders $\varnothing$ kelser kunnet konstatere at de fleste innfødte engelsktalende har et visst kjennskap til vitenskapelig terminologi, og at de er i stand til å skille mellom allmenn engelsk og vitenskapelig terminologi. De er i stand til å skille mellom den vitenskapelige og den allmenne betydning av ord som animal og plant. De to betydningene er klart adskilte, og alle språkbrukerne (enten de er lekmenn eller fagfolk) kan "skifte kode" mellom de to (Wierzbicka 1985, 155f).

Om fagmannen har spesialkunnskap om for eksempel epler, så er han i stand til å skille ut denne spesialkunnskapen fra kunnskapen som tilhører allmennspråket (op.cit., 214).

Denne evnen er i seg selv en type kunnskap som likner på Chomskys intuitive kunnskapsbegrep. Det er en kunnskap om språk, en følelse eller varhet overfor grenseoppganger i språket.

Denne språkevnen harmonerer med Wierzbickas syn på begreper (både i FS og i AS) som normer: Begrepene er folks antakelser om hva andre folk kan tenkes å si om for eksempel epler, kyr eller hunder (op.cit., 215).

Disse normene gjør seg gjeldende både i FS og i AS, men normene i AS er forskjellige fra normene i en FS-sammenheng. Både fagmannen og lekmannen har AS-normene, mens fagmannen har en mer komplett oversikt over FS-normene innen "sin" teknolekt, som lekmannen i større eller 
mindre grad har et vagt forhold til.

Som vi sa, evnen til å "skifte kode", eller "oversette fra FS til AS" (noe vi skal drøfte nærmere i forbindelse med økonomi) er en evne som også fagmannen har. For å ta Wierzbickas eksempel: En god veterinær må kunne skille sin kunnskap om kyr og sitt eget FS-begrep $k u$ fra sine klienters begrep $k u$, ellers ville han ikke kunne kommunisere med sine klienter om dyrene deres (loc.cit).

Den intuitive følelsen for grenseoppganger mellom FS og AS synes altså å være til stede, i alle fall på begrepsplanet.

Om man kan operere med et slikt intuisjonsbegrep på større nivåer, som syntaks og tekststrategi, er mer uklart, men det er ikke urimelig å anta at for eksempel en teknologistudent i løpet av sin utdannelse utvikler en slags følelse overfor rekurrente syntaktiske og tekstuelle særtrekk ved sitt fag på samme måte som en fremmedspråksstudent synes å utvikle en slags "teft" overfor strukturene i det språket han/hun studerer.

Et annet kunnskapsbegrep som stadig oftere nevnes i FS-litteraturen er kommunikativ kompetanse (Hymes 1970). Begrepet ble først anvendt i sosiolingvistikken, men har senere også stått sentralt hos flere tekstlingvister, og er kommet inn i FS-forskningen fra tekstlingvistikken.

Hymes' begrep refererer til en idealisert person som behersker et språks totale antall semiotiske systemer. Denne "perfekte" personen tilskrives all den kunnskap en innfødt språkbruker må ha for å kunne produsere og forstå kontekstuelt vellykkede og forståelige ytringer i det språket. Den lingvistiske kompetansen til Chomsky er bare en del av denne. Kommunikativ kompetanse omfatter ikke bare kontekstuavhengige fenomener som morfo-syntaks og formelle aspekter ved semantikken, men også kontekstsensitive elementer som tekstualitet, kohesjon og koherens.

Det er naturlig å trekke veksler på tekstlingvistikken, hvis studieobjektet er tekster, og hvis forskningsfeltet er den totale kommunikative situasjon (dvs mengden av kommunikative situasjoner som en tekst inngår i). Den kommunikative kompetansen blir da en overordnet ramme i dette bildet.

Teksten blir da, som Roald påpeker, en diskurs bestående av tekstlig realiserte semantiske, morfologiske, leksikalske og syntaktiske fenomener.

Det fører blant annet til en inndeling av tekster etter type talehandling (slik Sager foreslår) for eksempel direktive, argumentative, informative og klassifikatoriske talehandlinger.

Videre inngår en analyse av kunnskapsforholdet mellom avsender og 
mottaker som en del av dette bildet. Det gir utslag i variabler som slår ut $i$ en vertikal modell av FS.

For å kunne analysere tekster trenger man modeller og teorier som tillater oss å gå ut over setningsplanet. Et sentralt eksempel fra moderne FS-forskning er Hoffmanns kumulative tekstanalyse (Hoffmann 1983).

Analysen resulterer i to typer trekk: For det første koherenstrekk, som omfatter talehandlingstyper og tekstinnhold med særlig vekt på måten den er fremstilt på (presisjonsnivå, grad av språklig økonomi, grad av objektivitet, bruk av anafori etc.).

For det andre kohesjonstrekk, som i tekstene går på formelle uttrykksegenskaper (som grad av nominalisering, bruk av passiv og funksjonsverb, tempusbruk, bruk av personlige pronomen etc.).

En koherensanalyse vil innebære ikke bare en vurdering av avsenders kunnskapsdybde, men også en vurdering av avsenders vurdering av mottakers kunnskapsdybde. Det vil blant annet påvirke tekstens tematiske progresjon (dvs. forholdet mellom tema og rema, eller mellom kjent og ny informasjon). Dette virker klart inn på tekstutformingen.

Koherensanalysen innebærer også en vurdering av avsenderens sosiale status i forhold til mottakeren. Dette forholdet kan virke inn på type talehandling avsenderen kan tillate seg å anvende: Det å gi instrukser impliserer for eksempel normalt at avsender har høyere status eller autoritet enn mottaker.

I det følgende skal vi gå nærmere inn på noen trekk som regnes som særlig typiske i FS-tekster: nominalisering, økonomi og entydighet.

Flere forskere hevder at nominalisering og entydighet i FS-tekster henger sammen med FS's høye presisjonsbehov. Hoffmann $(1984,31)$ nevner for eksempel det høye antallet substantiviske attributter som et sentralt trekk. Høyt presisjonsbehov betinger valg av kategorier som har rike og nyanserte modifikasjonsmuligheter. Ser vi på NPer og VPer i norsk, kan indre oppbygging tyde på at NPer har større modifikasjonsmuligheter en VPer. For oversikthetens skyld kan vi sette opp en liste over noen sentrale trekk ved den interne strukturen av NPer og VPer i norsk (uten å gjøre krav på fullstendighet): 
NP:

modifikatorer:

- adjektiver (beskrivende, klassifiserende)

- determinativer (denne, disse, slike, fleste, færreste, enkelte, ...)

— ledd som kan inngå sammensetninger med kjernen

- relativsetninger grammatiske kategorier: kasus (genitiv) numerus bestemthet genus
VP:

modifikatorer:

- adverb

— ledd som kan inngå sammensetninger med kjernen

grammatiske kategorier: tempus modalitet (vilje ønske, irrealitet, etc.) diatese (aktiv, passiv)

Et interessant spørsmål blir da om disse formelle syntaktiske aspektene kan relateres til referanse- og klassifikasjonsbehovene i FS.

I FS-tekster refereres det ofte til hendelser, tilstander og egenskaper primært for å beskrive og klassifisere dem. De refereres til som fenomener som metoder og som prosesser.

Dette disponerer klart for nominalisering. Det er for eksempel naturlig å snakke om fenomenet oksydering, la det være tematisk utgangspunkt, og foreta utsagn om fenomenet.

Ser vi på adjektivene, er de hovedsakelig beskrivende eller klassifiserende, og egner seg godt som kommunikativt redskap i FS-tekster. Determinativer har som sentral oppgave å trekke ut delmengder av helmengder for å referere til, identifisere, beskrive og klassifisere. Den attributive genitiv vil ha som funksjon å angi relasjoner mellom nominale enheter og har adjektivets beskrivende og klassifiserende funksjoner.

Preposisjoner kan også utføre samme oppgaver som den attributive genitiv. Ledd som danner sammensetninger med kjernen i NPer har også klare klassifiserende og deskriptive egenskaper, og anvendes mye i terminologiske klassifikasjonssystemer, for eksempel ved generisk subklassifisering: ventiler, stengeventiler, reguleringsventiler, etc).

Ved verbalfrasene brukes adverbene for å kategorisere og klassifisere handlinger og tilstander. Det samme kan vel sies om ledd som danner sammensetninger med kjernen i VPer.

Men, som vi ser, den sentrale oppgaven å trekke ut, identifisere og klassifisere delmengder i helmengder, utføres i stor grad ved determinativene, som primært slutter seg til NPer i norsk. 
Det samme kan sies om relativsetningene, som typisk er nominale attributter. Deres hovedfunksjon er å avgrense og modifisere utsagn; et behov som er større i vitenskapelig og teknisk språk enn i AS.

En annen rent syntaktisk faktor i norsk som kanskje er verd å vurdere $\mathrm{i}$ denne sammenhengen er NPers mobilitet: NPer kan flyttes rundt det finitte verbet i predikatet i fortellende hovedsetninger. VPer er i mye større grad bundet syntaktisk. Dette fører til at NPer i mye større grad kan anvendes i syntaktisk tekststrategisk manipulasjon: Man har mulighet for spisstilling og dermed tematisering av NPer for å angi gitt informasjon, eller plassering i ulike postverbale posisjoner for å angi at informasjonen er ny og viktig. Forfatteren har med andre ord syntaktisk frihet til å vekte informasjon ved å manipulere med ordstilling. Det er det finitte verbet som er det faste, ikke-flyttbare elementet her.

Hva så med anaforisk referanse i forholdet NP og VP?

En FS-tekst kan, som vi sa, sees på som et sett av utsagn basert på begrepshierarkiene i vedkommende teknolekt.

For å kunne binde sammen begreper i en tekst (enten den er allmennspråklig eller fagspråklig) trenger man anaforisk referanse, mulighet for koreferanse mellom begreper:

Dette er en reguleringsventil. Ventilen/den har som hovedoppgave å.....

Anaforisk referanse er en typisk NP-oppgave i tekst (jf at Lyons kaller dem referring expressions (Lyons 1977, 177ff).

Hvilke anaforimuligheter fins ved verbet i VPer? Verbet gjøre har en typisk koreferanseoppgave i norsk:

Per hopper, og det gjør Kari også

Men selv her trenger man en NP (det) for å opprettholde koreferansen. Anaforisk referanse synes altså å være en egenskap som primært knytter seg til NPer.

Vi skal være forsiktige med å trekke for bastante slutninger av dette, men følgende påstander kan iallefall betraktes som arbeidshypoteser:

1. NPer har større interne modifikasjonsmuligheter enn VPer.

2. NPer har større syntaktisk frihet enn VPer.

3. NPer har større anaforimuligheter enn VPer.

4. NPer lar seg lettere taksonomisere enn VPer.

Den siste hypotesen kan forklares ut fra NPers og VPers typiske semantikk. De typiske kjerneelementene i VP og NP er V og N. Det typiske innholdet i V er handling - et dynamisk begrep som er mer komplekst 
og heterogent enn det typiske innholdet i N, som er konkrete objekter, altså statiske enheter. Objekter lar seg lettere relatere til helmengder og delmengder, og det er dermed lettere å etablere hyperonym/hyponym-relasjoner mellom dem.

Poenget er her at man ved å studere syntaktiske trekk fra en kommunikativ synsvinkel kan si noe om bruken av FS-trekk som for eksempel bruk av nominalisering.

Platzack (1977) har studert substantiver og nominale uttrykk fra en kognitiv psykologisk synsvinkel, og kommet til at nominale uttrykk ofte er lettere å huske enn tilsvarende verbale uttrykk. Kanskje kan det forklares med referanse til punkt 3 og (særlig) punkt 4.

Begrepet $\varnothing$ konomi har en kontroversiell historie i lingvistikken. Mest kjent er vel Martinets $\varnothing$ konomibegrep, koplet med hans inertiabegrep og funksjonell belastning (Martinet 1955). Disse ideene har senere også dukket opp innenfor språkplanleggingsteori (Tauli 1968).

Tre av Taulis økonomiprinsipper er verd å se nærmere på i forbindelse med forholdet mellom termer, definisjoner og forklaringer i FS-tekster:

For det første, optimal språklig økonomi tilsier at antallet språklige uttrykk må være lavest mulig uten at informasjon går tapt. Det innebærer for FS/TL at antallet leksikalske enheter både i systemet og i teksten må være så lavt som mulig så lenge entydighet kan opprettholdes.

For det andre må uttrykket være så kort som mulig.

For det tredje må ikke uttrykket formidle mer informasjon enn det som er nødvendig (Tauli op.cit., 32).

Disse $\varnothing$ konomiprinsippene finner man igjen i Grices pragmatiske teori om implikaturer. dvs en analyse av spenningsfeltet mellom det sagte (uttrykket) og det impliserte i konversasjoner. Selve økonomiprinsippet formulerer Grice i form av 4 konversasjonsmaksimer som danner fundamentet for fremmingen av effektiv kommunikasjon av proposisjonalt innhold (som jo er et overordnet mål i FS-tekster):

\footnotetext{
"Quantity. (i) Make your contribution as informative as is required (for the current purposes of the exchange); (ii) do not make your contribution more informative than is required. quality. Try to make your contribution one that is true: (i) Do not say what you believe to be false; (ii) Do not say that for which you lack adequate evidence. Relation. Be relevant. Manner. Be perspicuous: (i) Avoid obscurity of expression, (ii) Avoid ambiguity; (iii) Be brief (avoid unnecessary prolixity); (iv) Be orderly" (Lyons 1977, 593).
}

Taulis tre prinsipper faller inn under Grices kvantitets-maksime. Kvalitetsmaksimen angir forholdet mellom avsenders og mottakers kunn- 
skapsdybde. Relasjonsmaksimen om relevans er et grunnlag som tematisk og makrostrukturell analyse må hvile på, og som er avgjørende for teksters koherens. Den er derfor en sentral maksime for tematisk tekstanalyse og indeksering.

Modalmaksimen (manner) harmonerer godt med terminologiens normative idealprinsipper om entydige og velordnede begrepssystemer.

Det interessante med Grices perspektiv er at dette inngår som del av en analyse av den ideelle språkbrukerens kommunikative kompetanse. Perspektivet blir dermed annerledes. Det er ikke lenger bare snakk om påbud og forbud som man må forholde seg til hvis man skal drive terminologiarbeid og skrive FS-tekster, men en analyse av språkbrukerens kompetanse. Det er ikke lenger snakk om normer vi lager oss for å fremme effektiv kommunikasjon, men egenskaper ved naturlig språk (både AS og FS) som er sentrale og nødvendige for enhver overføring av kommunikasjon ved hjelp av språk.

I FS-sammenheng optimaliseres i større grad Grices økonomiske maksimer enn i AS. Som del av den kommunikative kompetansen kan dette danne en del av rammene og utgangspunktet for studiet av FS-tekster. FS vil da neppe kunne betraktes som en autonom disiplin med et eget studieobjekt i kvalitativ forstand. Men studiet av FS-tekster, så langt det er mulig å definere dem som FS-tekster, vil kunne yte verdifulle bidrag til pragmatikken.

Den praktiske nytten av dette har man allerede sett konsekvensen av innenfor kunstig intelligens og ekspertsystemer, hvor økonomi og entydighet er av avgjørende betydning for tilrettelegging for datamaskinell behandling.

Som nevnt har kunstige språk flere trekk til felles med FS, blant annet entydighet og økonomi. Dette ser vi klarere hvis vi prøver å oversette for eksempel predikatskalkyler i symbolsk notasjon til naturlig språk. Hvis entydigheten skal opprettholdes, blir syntagmene (det lineære uttrykk) lengre i det naturlige språket.

På samme måte som man kan se på kunstig språk som en "oversettelse" fra naturlig språk, kan definisjoner og forklaringer sees på som en oversettelse fra FS til AS. Dette synet finner vi eksempel på i leksikografien hos Knudsen et al (1957) hvor man foreslo å anvende Hjelmslevs kommutasjonstest for å måle definisjoners brukbarhet i Norsk Riksmålsordbok. En ordboksdefinisjon burde være istand til å erstatte et ord i en vanlig setning (Knudsen et al op. cit., 124). 
Det samme kravet til definisjoner finner man også i FS og TL:

"-definisjonen utformas så att den, utan ändringer, kan sättas i termens ställe i en løpande text" (Laurén 1985, 84).

I moderne leksikografi har man innsett at denne kommutasjonstesten er umulig, fordi et leksem (som en ordboksdefinisjon representerer) tilhører et mer abstrakt nivå enn ordformer i tekster. Som Greimas påpeker gis leksemet kun en partiell realisering $i$ en tekst eller en diskurs (Greimas 1981, 196).

Men selv om kommutasjonsprinsippet bunner i manglende evne til å holde leksemnivå og tekstnivå fra hverandre, sier den likevel noe om definisjonens kommunikative funksjon.

La oss derfor se litt nærmere på implikasjonene av Lauréns krav. I TL er definisjonen en språklig (forklarende) formulering av et fagbegrep. Fagbegrepet representeres språklig av en term i FS-tekster. Av det følger at fagterm og definisjon skal referere til samme begrep. Sagt på en annen måte: Definiendum, det som skal defineres (termen) skal kommunikativt sett være ekvivalent med definiens, det som definerer (definisjonen).

Hovedforskjellen blir da at definiendum er kort mens definiens normalt er lengre enn definiendum, nettopp fordi definiens skal forklare definiendum.

Forenklet sett kan vi si følgende: Hvis fagbegrep a skal kommuniseres fra person P1 til P2 kan den korte definiendum brukes hvis P2 kjenner begrepet (og termen som brukes). Hvis $\mathrm{P} 2$ ikke kjenner definiendum, må den lengre definiens erstatte definiendum.

Jo færre definiendumer P2 kjenner innenfor et emne, desto flere fagspesifikke (korte) definiendumer (termer) må erstattes med lengre definienser eller tilsvarende lange omskrivninger og forklaringer. Roald sier det samme på en litt annen måte:

"Det ville være uforholdsmessig tungt og uøkonomisk å bruke definisjonene i løpende tekst, i tegninger, diagrammer o.l. Derfor trenger vi termene (som vi kan betrakte som kortformer for definisjonene)" (Roald 1985, 257).

Men språklig økonomi er det logisk komplementære til språklig redundans. Som Platzack sier (med referanse til Findal og Höijer):

"Genom att bygga ut meddelandet med vad vi skulle beteckna som språklig "semantisk" redundans eller tillskottsinformation kan man göra meddelandet mindre känsligt for störningar. Med tillskottsinformation avser vi den information som tilførs meddelandet i dess kortast tänkbara utformning... Dette kan i viss mening betraktas som sløseri eftersom man gör meddelandet längre och mer omfattande utan att egentligen tillföra ny information. Men samtidigt utgör det 
ett ändamålsenligt skydd mot forväxlingar och misstag. Mottagaren ges ökade möjligheter att uppfatta innehållet även om delar av meddelandet inte når fram. Det blir lättare att gissa seg till de delar man gick miste om" (Platzack 1977, 6).

Hvis det er mulig å tenke seg en FS-tekst uten terminologi og kunstig språk (som tabeller, modeller og andre formalismer), vil mye mer av den språklig økonomiske gevinst gå tapt. Økonomiegenskapen ved FS hviler altså i stor grad nettopp på innslaget av terminologi og kunstig språk.

I enhver språkkommunikativ sammenheng er det altså et samspill mellom økonomi og redundans som er styrt av behovet for entydighet og presisjon på den ene siden, og behovet for forståelighet på den andre siden.

Dette aktualiserer populariseringsaspektet i FS-tekster, et spørsmål som har relevans for avgrensingsproblematikken vår: Når slutter FS og når begynner AS? Som Roald påpeker gjør populariseringsaspektet ved FS avgreningen mellom AS og FS uklar:

\footnotetext{
"Mindre klart blir bildet når mottaker ikke kan karakteriseres som $\mathrm{F}<\mathrm{F}=$ fagmann, PA>. Er det meningsfylt å betrakte en F-lekmann-kommunikasjon som realisering av FS?.... I f. eks. et populærvitenskapelig arbeid vil avsender, for å oppnå en vellykket kommunikasjon, justere utsagn om begrepshierarkier etter mottakergruppens antatte forutsetninger (omskrivninger i stedet for tekniske termer, eksplisitering på tekstnivå av en rekke karakteristiske trekk ved begrepet o.1.)" Roald 1986a, 184).
}

Vil en sterkt popularisert FS-tekst i hovedsak skille seg fra en ikkepopularisert FS-tekst ved at termer og bruk av kunstig språk er erstattet av definisjoner, forklaringer og omskrivninger (hvis vi antar at det denotative innholdet er identisk i de to variantene)?

Kan man for eksempel si at det er et omvendt proporsjonalt forhold mellom bruk av syntagmene (bruk av definisjoner og forklaringer) og bruk av paradigmene (bruk av termer) for å få fram begreper i FS-tekster? Vil dette være variabler som leder fra FS til AS via popularisering? Vil en popularisert FS-tekst m.a.o. belaste språkets syntagmatiske dimensjon på bekostning av den paradigmatiske, og dermed gi avkall på språklig $\emptyset$ konomi for å lette forståeligheten?

Hvis man som fagmann skal omtale et emne eller problem-kompleks til en faglig sett utenforstående, er det mange termer man ikke kan bruke. Man må da erstatte termene med definisjoner og forklaringer for å opprettholde forståelsen hos mottakeren, samtidig som presisjonsnivå og entydighet skal opprettholdes.

Hvis dette er tilfellet, så blir definisjonen en oversettelse fra FS til AS; 
en kommunikativ brobygger mellom de to. Av det følger logisk at definisjoner ikke kan vurderes fyldestgjørende i et abstrakt vakuum, men må formuleres med utgangspunkt i situasjon og brukergruppe.

Dette harmonerer med tesen om at FS-varianter er parasittiske på AS, men synes å bryte med Thomas Kuhns tese om at observasjoner er "paradigmeimpregnerte" i den forstand at data og observasjoner kun er forståelige gjennom det paradigmet, eller den faglige matrisen, de tilhører. Hvis paradigmer skal kunne konkurrere med hverandre, må de være gjensidig forståelige.

Hvis man, som et tankeeksperiment, forestiller seg at to ulike FS-varianter overlapper med to ulike faglige matriser, så vil disse to variantene $\mathrm{i}$ alle fall være indirekte kommensurable, fordi de begge er parasittisk på $\mathrm{AS}$, som jo har et gjennomgripende sett av normer som FS-variantene må relatere seg til.

Hittil har vi omtalt $\varnothing$ konomi, entydighet og presisjon i synkront perspektiv. Hvordan slår så dette ut diakront?

Det komplementære motstykket til presisjon er vaghet, en egenskap som er typisk for AS. Dette ser man tydeligst i AS-leksikon, som er fullt av vaghet og flertydighet (polysemi).

Man kan saktens spørre seg hvorfor det er slik. Burde ikke AS være like presist og entydig som FS? Ville ikke vi alle da ha et mer effektivt og praktisk kommunikasjonsredskap til beste for alle?

Det er flere grunner til at vaghet og flertydighet er nødvendig i AS (typene kommunikative situasjoner og avsenders intensjoner har med dette å gjøre).

Forskningen innen dialektologi og sosiolingvistikk har vist at AS endrer seg svært langsomt. Når det gjelder språkets leksikon er en vesentlig årsak til dette nettopp AS-leksikonets vage og polyseme karakter.

Disse egenskapene fører til at allmennspråklige begreper er lett å tilpasse en verden i stadig forandring. For å bruke en Saussursk metafor: Språket er en kledning dekket med lapper fra sitt eget tøy (Saussure 1970, 209). I FS/TL vil enhver endring føre til at nye begreper oppstår, og behovet for å gi det eget entydig uttrykk oppstår; eller det gamle uttrykket beholdes, men må få nytt begrepsinnhold og ny definisjon (f.eks. typen atom, som betyr "udelelig", men som ved nyere teknikk kan spaltes).

I allmennspråket vil det språklige uttrykket lettere kunne beholdes selv om innhold endres, fordi det i langt større utstrekning tåler polysemi. Språk som vietnamesisk, og særlig de polynesiske språkene, viser at ter- 
skelen for hvor mye polysemi som tåles i allmennspråk er svært høy.

På grunn av den lave polysemiterskelen i fagspråkets terminologi blir oppdatering et stort praktisk problem. Dette er den prisen man må betale når man skjærer vekk en sentral egenskap ved naturlig språk. Vaghet og flertydighet er to av språkets immunsystemer mot "tidens tann", og er en viktig del av språkets kybernetiske, selvregulerende egenskaper. De gjør AS til et tilpasningsdyktig kommunikasjonssystem. Som konklusjon og oppsummering kan vi sitere Pichts definisjon av FS:

"LSP is a formalized and codified variety of language used for special purposes and in a legitimate context - that is to say, with the function of communicating information of a specialist nature at any level - at the highest level of complexity, between initiate experts, at lower levels of complexity, with the aim of informing or initiating other interested parties, in the most economic, precise and unambiguous terms possible" (Picht et al 1985, 3).

Vi ser at definisjonen legger vekt på formål, på språkets kommunikative funksjon, på grad av kompleksitet. Den inkluderer populariseringsaspektet og har ellers stikkordene økonomi, presisjon, og entydighet.

I FS-forskningen bør etter mitt syn et overordnet mål være følgende: Beskrivelse og forklaring av de "faglige verdener", deres selvforståelse, problematiseringer og temafokuseringer på den ene siden, og de systemutslag disse variablene gir på det språklige uttrykket. En slik målsetning har som konsekvens at studieobjektet for FS også vil være relatert til ulike fagområders avgrensingsproblematikk.

Fordi disse variablene kan tenkes å gi systemutslag på alle språklige nivåer (kanskje med unntak av fonologien), er tekster det naturlige utgangspunktet.

\section{Litteratur}

Ammon, Uriel (1973): Indføring i Sociolingvistik. København: Gyldendals Sprogbibliotek.

Arntz, Reiner og Picht, Heribert (1982): Einführung in die übersetzungsbezogene Terminologiearbeit. Hildesheim: Georg Olms Verlag.

Baldinger, Kurt (1952): Die Gestaltung des wissenschaftlichen Wörterbuchs, i: Romanisches Jahrbuch. Hamburg.

Beaugrande, Robert de (1984): Text Production. Toward a Science of Composition. New Jersey: Ablex Publ. Company.

Beaugrande, Robert de (1987a): Special purpose language and linguistic theory, i: Unesco Alsed-LSP København: Newsletter. vol. 10, no 2 (25).

Beaugrande, Robert de (1987b): Determinacy distributions in complex systems, i: Science, linguistics, language, life. Zeitschrift für Phonetik, Sprachwissenschaft und Kommunikationsforschung, 40.

Chomsky, Noam A. (1985): Knowledge of Language. Cambridge.: Praeger. 
Dahlberg, Ingetraut (1974): Grundlagen universaler Wissensordnung. München: Verlag Dokumentation.

Drozd, Lubomir og Seibicke, Wilfred (1973): Deutsche Fach- und Wissenschaftssprache. Wiesbaden: Oskar Brandstetter Verlag.

Galinski, Christian og Nedobity, Wolfgang (1986): Eine terminologische Datenbank als Managementinstrument, i: Unesco Alsed-LSP Newsletter. vol. 9, no 2.

Geckeler, Horst (1982): Strukturelle Semantik und Wortfeldtheorie. München: Wilhelm Fink Verlag.

Grice, H.P. (1975): Logic and Conversation, i: S. Cole og Morgan, J.L.: Syntax and semantics, 3: Speech Acts. New York: Academic Press.

Greimas, Algirdas Julien (1981): Aktanter, aktører och figurer, i: Kaminsky, Jerzy og Laven, Gösta (red.): Textkoherens. Uppsala: Uppsala Slavic Papers.

Haarala, R. (1983): Språkvård och terminologi, i: Språk i Norden. Nordisk språksekretariats skrifter 2 .

Halliday, Michael Alexander Kirkwood (1969): Existing research and future work, i: Language for Special Purposes. London.

Halliday, Michael Alexander Kirkwood, McIntosch, Angus og Stevens, P. (1964): The Linguistic Sciences and Language Teaching. London: Oxford University Press.

Hjelmslev, Louis (1943): Omkring Sprogteoriens Grundlaggelse. København: Festskrift Københavns Universitet.

Hoffmann, Lothar (1976): Kommunikationsmittel Fachsprache. Berlin.

Hoffmann, Lothar (1979): Towards a theory of LSP, i: Fachsprache. 1, 1/2. Wien: Wilhelm Braunmüller.

Hoffmann, Lothar (1983): Fachtextlinguistik, i: Fachsprache. 2. Wien: Wilhelm Braunmüller.

Hoffmann, Lothar (1984): Seven Roads to LSP, i: Fachsprache. 1-2. Wien: Wilhelm Braunmüller.

Hoffmann, Lothar (1985): On the place of LSP Research in Applied Linguistics, i: Fachsprache. 1-2. Wien: Wilhelm Braunmüller.

Hoffmann, Lothar og Piotrowski, Rajmond Genrichovic (1979): Beiträge zur Sprachstatistik. Leipzig.

Hymes, Dell (1970): On Communicative Competence. Philadelphia: University of Pennsylvania Press.

Jumpelt, R.W. (1961): Die Übersetzung naturwissenschaftlicher und technischer Literatur. Berlin.

Kaminsky Jerzy de og Laven, Gösta (1981): Tekstkoherens. Nye riktninger $i$ studiet av textens struktur. Uppsala.

Katz, Jerrod Jakob og Fodor, Jerry A. (1963): The structure of a semantic theory, i: Language 39.

Knudsen, Trygve og Sommerfelt, Alf (1957): Principles of Unilingual Dictionary Definitions, i: Reports for the Eight International Congress of Linguistics. Oslo.

Kuhn, Thomas (1970): The Structure of Scientific Revolution. Chicago: The University of Chicago Press 
Laisiepen, Klaus, Lutterbeck, Ernst og Meyer Uhlenried, Karl-Heinrich (1980): Grundlagen der praktischen Information und Dokumentation. München: K. G. Sauer.

Laurén, Christer (1984): Fackspråk och teknolekter, i: Nordisk tidsskrift for fagspråk og terminologi. 84/1.

Laurén, Christer (1985): Definisjon och forklaring, i: Nordisk Terminologikursus II. Skodsborg.

Laurén, Christer (1987a): Abstracts. 6th European Symposium on Language for Specific Purposes. Vaasa.

Laurén, Christer (1987b): Hur mycket syns jag i facktexten, i: Fackspråk och oversettningsteori. Vaasa.

Laurén, Christer og Nordman, Marianne (1985): Projektet svenskt fackspråk. Bakgrund, mål och korpus. Vaasa.

Lyons, John (1977): Semantics. I og II. Cambridge: Cambridge University Press.

Martinet, André (1955): Economie des changements phonétiques. Bern: Biblioteca Romanica.

Picht, Heribert (1985a): Terminologiens forskningsgenstand og relasjon til andre discipliner, i: Nordisk Terminologikursus II. Skodsborg.

Picht, Heribert (1985b): Leksikografi - terminografi, i: Nordisk Terminologikursus II. Skodsborg.

Picht, Heribert (1985c): Begrepet som sentralt element i terminologilæren, i: Nordisk Terminologikursus II. Skodsborg.

Picht, Heribert (1987): Fachsprachliche Phraseologi - die terminologische Funktion von Verben, i: Terminologie et traduction, 3.

Picht, Heribert og Draskau, Jennifer (1985): Terminology: An Introduction. Universtiy of Surrey.

Platzack, Christer (1977): Substantivsjuka - ett friskhetstecken?. i: Lundastudier i nordisk språkvetenskap. D 12. Lund.

Popper, Karl Raimond(1980): The logic of Scientific Discovery. London: Hutchinson.

Pustejovsky, James (1988): Knowledge Representation and the computational Lexicon. Pisa Summer School. Pisa: Handout Series.

Ralph, Bo (1980): Hur mycket fackspråk er fackspråk? i: Svenskans beskrivning. 12.

Rangnes, Odd Kjetil (1988): Hva skal dingsen hete? Brannslukkingsutstyr på Gullfaks B. En terminologisk analyse. Hovedfagsoppgave ved Nordisk institutt. Universitetet i Bergen, i: Norske Språkdata 19.

Riiber, Theis (1981): Pilotstudie i excerpering af fagsprog, i: Ark. 11. København.

Roald, Jan (1985): Termen - et faglig begreps uttrykksside, i: Nordisk Terminologikursus II. Skodsborg.

Roald, Jan (1986a): Om begrepet fagspråk, i: Romansk fra vest. Bergen.

Roald, Jan (1986b): Terminolprosjektet. Sluttrapport fra et terminologisk prosjekt. Norske Språkdata 11 (rød serie) Bergen: Norsk Termbank.

Rondeau, Guy (1982): Linguistics and terminology, i: Vasa Proceedings of Nordic Seminar on LSP and Terminology. Vasa. 
Rosch, Eleanor (1973): On the internal structure of perceptual and semantic categories, i: T.E. Moore (red.): Cognitive Development and the Aquisition of Language. New York: Academic Press.

Sager, Juan Carlos, Dungworth, David og McDonald, Peter F. (1980): English Special Languages. Wiesbaden: Oscar Brandstetter Verlag.

Sager, Naomi (1982): Syntactic formatting of science information, i: Kittredge, Richard og Lehrberger, John (red): Sublanguage. Studies of Language in Restricted Semantic Domains. de Gruyter: Berlin.

Saussure, F. de (1970): Kurs i allmänn lingvistik. Paris: Bo Cavefors Bokförlag.

Spiegel, Heinz Rudi (1985): Fachsprachenforschung und Terminologiearbeit, i: Nordisk Terminologikursus II. Skodsborg.

Stortingsmelding nr 35 (1975-76): Om forskningens organisering og finansiering.

Svindland, Arne Sivert (1985): Om definisjonen av "anvendt lingvistikk". i: Skriftserien. Institutt for fonetikk og lingvistikk. Bergen.

Tauli, Valter (1968): Introduction to a Theory of Language Planning, i: Acta Universitatis Upsaliensis. Uppsala.

Thelander, Mats (1974): Grepp och begrepp i språksociologin. Lund: Studentlitteratur.

Thompson, Laurence C. (1965): A Vietnamese Grammar. Seattle: University of Washington Press.

Turner, G.W. (1973): Stylistics. Hammondsworth: Pelican Books.

Vinje, Finn-Erik (1983): Fagspråk i mediesamfunnet, i: Språk i norden.

Wierzbicka, Anna (1985): Lexicography and Conceptual Analysis. Ann Arbor: Karona Publishers inc.

Wüster, Eugen (1969): Die vier Dimensionen der Terminologiearbeit, i: Mitteilungsblatt für Übersetzer und Dolmetscher.

Wüster, Eugen (1971): Begriffs- und Themaklassifikationen. Unterschiede in ihrem Wesen und in ihrer Anwendung, i: Nachrichten für Dokumentation. 22, nr 3. Frankfurt.

Wüster, Eugen (1974): Die allgemeine Terminologielehre - ein Grenzgebiet zwischen Sprachwissenschaft, Logik, Ontologie, Informatik und den Sachwissenschaften, i: Linguistics. An international Review. 119. Mouton: The Hague.

Wüster, Eugen (1985): Einführung in die allgemeine Terminologielehre und terminologische Lexikographie. København: The LSP Centre. UNESCO Alsed. LSP Network.

Yates, F.E. og Beaugrande, Robert de (1987): Physics and Semiotics, i: W. Koch (red.): Semiotics and the individual Sciences. Bochum: Brockmeyer.

Zgusta, Ladislav (1971): Manual of Lexicography. Mouton: The Hague. 